\title{
A Primer on Market Discipline and Governance of Financial Institutions for Those in a State of Shocked Disbelief*
}

\author{
Joseph P. Hughes \\ Rutgers University
}

and

\section{Loretta J. Mester}

Federal Reserve Bank of Philadelphia

and

The Wharton School, University of Pennsylvania

This paper was invited for submission to Efficiency and Productivity Growth in the Financial Services Industry, edited by Fotios Pasiouras, John Wiley and Sons.

\begin{abstract}
Self regulation encouraged by market discipline constitutes a key component of Basel II's third pillar. But high-risk investment strategies may maximize the expected value of some banks. In these cases, does market discipline encourage risk-taking that undermines bank stability in economic downturns? This paper reviews the literature on corporate control in banking. It reviews the techniques for assessing bank performance, interaction between regulation and the federal safety net with market discipline on risk-taking incentives and stability, and sources of market discipline, including ownership structure, capital market discipline, product market competition, labor market competition, boards of directors, and compensation.
\end{abstract}

*Correspondence to:

Mester at Research Department, Federal Reserve Bank of Philadelphia, Ten Independence Mall, Philadelphia, PA 19106-1574; phone: 215-574-3807; fax: 215-574-4303; email: Loretta.Mester@phil.frb.org.

Hughes at Department of Economics, Rutgers University, New Brunswick, NJ 08901-1248; email:jphughes@rci.rutgers.edu.

The views expressed here are those of the authors and do not necessarily reflect those of the Federal Reserve Bank of Philadelphia or of the Federal Reserve System. This paper is available free of charge at www.philadelphiafed.org/research-and-data/publications/working-papers/. 


\title{
A Primer on Market Discipline and Governance of Financial Institutions for Those in a State of Shocked Disbelief
}

\author{
Joseph P. Hughes \\ Rutgers University \\ and \\ Loretta J. Mester \\ Federal Reserve Bank of Philadelphia \\ and \\ The Wharton School, University of Pennsylvania
}

\begin{abstract}
"Except where market discipline is undermined by moral hazard, for example, because of federal guarantees of private debt, private regulation generally has proved far better at constraining excessive risk-taking than has government regulation."
\end{abstract}

- Alan Greenspan, former Federal Reserve Board Chairman, in a speech to the Forty-first Annual Conference on Bank Structure at the Federal Reserve Bank of Chicago, May 2005

"When the music stops, in terms of liquidity, things will be complicated. But as long as the music is playing, you've got to get up and dance. We're still dancing."

- Charles O. Prince, former CEO and Chairman of Citigroup, in an interview by Nakamoto and Wighton in the Financial Times, July 2007

"...those of us who have looked to the self-interest of lending institutions to protect shareholders' equity (myself especially) are in a state of shocked disbelief."

- Alan Greenspan, former Federal Reserve Board Chairman, in testimony to the House Committee on Oversight and Government Reform, October 2008

\section{Introduction}

Self regulation encouraged by market discipline constitutes a key component of the third pillar of Basel II. As implied by the third pillar, markets are thought to punish the banks that imprudently take risk and reward those that do not. As former Federal Reserve Board Chairman Greenspan suggested, market discipline has traditionally been thought to enhance managerial 
performance and shareholder wealth, and to constrain excessive risk-taking. Empirical research has generally confirmed that, where market discipline is not impeded by managerial entrenchment, it has promoted efficiency and enhanced value. However, the comment of former Citigroup CEO Charles Prince, "we're still dancing," and his worry about the liquidity problems that will arise when the music stops suggest that high-risk investment strategies may maximize the expected value of some banks. If so, does market discipline in these cases encourage risktaking that erodes the stability of banks in economic downturns? And, what are the sources of these risk-taking incentives?

Compared with nonfinancial firms, commercial banks face unique risk-taking incentives. Marcus (1984) shows that regulatory limitations on entry and the mispriced federal safety net create dichotomous incentives for risk-taking. For banks with valuable investment opportunities, protecting their charters from episodes of financial distress by pursuing relatively less risky investment strategies maximizes their expected value. On the other hand, for banks with less valuable investment opportunities, say, because they operate in very competitive markets, exploiting the cost-of-funds subsidy due to implicit and explicit deposit insurance by pursuing relatively more risky investment strategies maximizes their expected value. For this latter type of financial institution, market discipline encourages risk-taking and may work against financial stability.

Managers with substantial undiversified investments of human capital and ownership stakes in their firms and managers who enjoy substantial private benefits of control may protect their advantages by avoiding higher risk investment strategies. However, diversified outside owners may prefer that managers pursue these risky investments. ${ }^{1}$ When they own enough of the firm to overcome managerial resistance, they can induce managers to adopt higher risk strategies that tend to maximize expected value. And, there are a variety of other sources of discipline, internal as well as external to the firm, that can ameliorate agency problems and improve individual firm performance, but not necessarily the stability of the financial system as a whole.

Competition among firms is thought to be one source of discipline. Many studies find an important role for competition in promoting efficiency. Competition among firms in markets for

\footnotetext{
${ }^{1}$ Gorton and Rosen (1995), however, show that the conflict between managers' and equityholders' risk-taking incentives also depends on the investment opportunities facing the bank. In an environment of declining investment opportunities, when bank managers receive private benefits of control and outside shareholders cannot perfectly control them, managers will tend to take on excessive risk. In contrast, when the industry has increasing investment opportunities, managers act too conservatively.
} 
products and services enhances managerial efficiency (Berger and Hannan, 1998). The efficiency of competitive labor markets in banking appears sufficient to distinguish poor managerial performance from poor firm performance and to hold senior managers accountable (Cannella, Fraser, and Lee, 1995). Moreover, relaxation of restrictions on interstate banking in recent years has increased competition in the market for corporate control and led to improved performance among underperforming banks whose management is not entrenched by means of higher insider ownership, lower outside block ownership, or less independent boards (Brook, Hendershott, and Lee, 1998). In banking, however, competition may be a two-edged sword: it can change risk-taking incentives, which then flows through to performance. For example, Keeley (1990) found that competition reduces the value of banks' charters and creates risktaking incentives. Grossman (1992) offered evidence that cost-of-funds subsidies that result from mispriced deposit insurance as well as lax supervision encourage bank risk-taking.

Ownership of stock by officers and directors can align the interests of insiders with outside owners (Jensen and Meckling, 1976, and Fama and Jensen, 1983), but it can also entrench insiders and lead to poorer performance (Morck, Shleifer, and Vishny, 1988). Similarly, ownership of stock by blockholders whose economic stake in the firm is large enough to overcome free-rider problems, can improve monitoring of insiders and, consequently, better align the interests of insiders with those of outside owners. However, when high-risk investment strategies maximize expected value, the influence of blockholders can increase bank risk-taking and threaten banking system stability in troubled economic times (Laeven and Levine, 2009).

In addition to market sources of discipline, arrangements internal to the firm can also ameliorate agency problems and improve performance. The board of directors monitors management, sets compensation of senior managers, and hires and fires the CEO. The board can structure managerial compensation contracts so that they lessen agency conflicts between managers and outside stakeholders. However, boards themselves may have agency conflicts and fail to put the optimal compensation structure in place. Core, Holthausen, and Larcker (1999) find that CEOs of firms with weaker governance structures earn higher compensation and that their firms perform worse than those with stronger governance. In contrast, Cheng, Hong, and Scheinkman (2010) find that financial institutions with institutional investors often provide unusually large compensation incentives to adopt high-risk investment strategies that typically 
perform well-above average in good economic times and well-below average in poor economic times.

Market discipline and internal governance interact with banking regulations and supervision to influence the performance and stability of banks. The components of market discipline and internal governance in the context of regulation are considered in the sections that follow. Section 2 describes a variety of techniques for assessing bank performance that are found in the literature on discipline and governance. Section 3 considers Chairman Greenspan's caveat on private regulation: how public regulation and the federal safety net interact with market discipline to influence risk-taking incentives and bank stability. Section 4 examines sources of market discipline: ownership structure, capital market discipline, product market competition, labor market competition, boards of directors, and compensation. Section 5 concludes.

\section{Assessing the performance of financial institutions ${ }^{2}$}

Investigations into the relationship of banks' financial performance to sources of market discipline and governance arrangements use accounting data and data on market value. Accounting data permit the construction of various measures of historical cost and profit. Unlike accounting data, market-value data include the market's valuation of expected future cash flows as well as current cash flow. The market's calculation of present value also contains its evaluation of a firm's discount rate - that is, its exposure to market-priced risk. Thus, performance measured by market value offers two advantages over accounting data: the evaluation of market-priced risk and future expected earnings. While some studies seek to evaluate banking performance in terms of quantities of inputs used to produce the outputs, the focus on quantities rather than value makes incorporating risk into the analysis extremely difficult. In fact, many studies that use accounting data as well as production data often ignore risk and reach misleading conclusions. This is explained further in Berger and Mester (1997), Hughes, Mester, and Moon (2001), and Hughes and Mester (2010). Consequently, we do not review the quantity-based approach.

\footnotetext{
${ }^{2}$ Hughes and Mester (2010) provide a more detailed discussion of measuring performance in banking.
} 
Bank performance can be measured using either a structural or a nonstructural approach. Let $y_{\mathrm{i}}$ represent the measure of the $i^{\text {th }}$ bank's performance. Let $\boldsymbol{z}_{\mathrm{i}}$ be a vector of variables that represent components of the $i^{\text {th }}$ bank's technology such as output levels and input prices. Let $\boldsymbol{\tau}_{\mathrm{i}}$ be a vector of variables affecting the technology, such as the number of branches and measures of asset quality. A number of studies reviewed below include a vector, $\boldsymbol{\theta}_{i}$, that characterizes the property-rights system, contracting, and regulatory environment in which the $i^{\text {th }}$ firm operates. This vector can include the characteristics of deposit insurance and legal protection of investors. In addition, the organization form and characteristics of market discipline and governance of the $i^{\text {th }}$ firm are included in a vector, $\boldsymbol{\varphi}_{i}$, which might include the degree of market concentration, the status of the firms as a mutual or stock-owned firm, the size of its board of directors, and the proportion of the bank's outstanding shares owned by officers and directors.

Letting $\varepsilon_{\mathrm{i}}$ represent random error, the performance equation to be estimated takes the form,

$$
y_{\mathrm{i}}=\mathrm{f}\left(\boldsymbol{z}_{\mathrm{i}}, \boldsymbol{\tau}_{\mathrm{i},} \boldsymbol{\varphi}_{\mathrm{i}}, \boldsymbol{\theta}_{\mathrm{i}} \mid \boldsymbol{\beta}\right)+\varepsilon_{\mathrm{i}} .
$$

The nonstructural approach specifies the performance equation in terms of either an accounting measure of performance, such as return on assets, or a measure based on market value, such as Tobin's $q$ ratio or cumulative abnormal return from an event-study model. It is less likely to focus on a detailed vector of input prices, outputs levels, or output prices in the specification of the vector $\boldsymbol{z}_{\mathrm{i}}$. Instead, it might consider how performance is related to the degree of market discipline and the quality of governance.

In contrast, the structural model incorporates an optimization assumption, such as profit maximization, cost minimization, or utility maximization. In the structural model of cost minimization, the vector $\boldsymbol{z}_{\mathrm{i}}$ characterizes the outputs banks produce and the prices of inputs used in bank production. In addition, the vector $\boldsymbol{\tau}_{\mathrm{i}}$ might include the level of equity capital and various measures of asset quality, such as the ratio of nonperforming loans to total assets. In measuring performance, the structural model is usually estimated as a frontier - a lower envelope in the case of cost and an upper envelope in the case of profit. Various parametric and nonparametric techniques have been developed to identify the best-practice frontier. ${ }^{3}$ The

\footnotetext{
3 Berger and Mester (1997) discuss several of these techniques and point out the advantages of the parametric techniques, such as stochastic frontier estimation and the distribution-free approach, over nonparametric techniques
} 
difference between the best-practice frontier and the observed practice represents, in the case of the cost function, excessive cost relative to best practice and, in the case of the profit function, lost profit relative to best practice. Having estimated cost or profit efficiency from the structural model, studies typically regress the efficiency estimate on a set of explanatory variables that could include measures of market discipline and the quality of governance.

When profit and cost are estimated by a frontier technique, the goal is to measure bestpractice technology and the failure to achieve it. Since the frontiers that are estimated are obtained by minimizing cost and maximizing profit, they fit the data for these best practices and, thus, do not provide a theoretical model to explain the inefficient behavior in the data captured by the frontiers. In a series of papers - Hughes, Lang, Mester, and Moon (1996, 2000), Hughes and Mester (2010, 2011), and Hughes, Mester, and Moon (2001) - the authors develop and estimate a model of managerial utility maximization that is sufficiently general to subsume profit maximization and cost minimization and, more generally, managerial objectives that trade profit for other objectives, such as risk reduction and the consumption of agency goods. Thus, the objective function that yields the equations they estimate allows for agency problems: it explains each bank's utility-maximizing expected return and return risk. It is a behavioral model that explains inefficiency. To estimate the inefficiency present in the data, the authors fit a stochastic frontier of expected return to return risk. The frontier yields the best-practice risk vs. expectedreturn frontier and each bank's lost return at its estimated risk exposure.

The utility maximizing expected return and return risk are estimated from a structural model of managerial behavior that allows for risk vs. expected-return inefficiency; however, the frontier is fitted as a nonstructural model and estimates the degree of inefficiency of each bank's predicted return given its return risk. Thus, this approach represents a hybrid of the standard model in which a minimum cost or maximum profit function is fitted as a best-practice frontier. Finally, the estimated inefficiency is explained by estimating equation (1) with the lost return as the dependent variable.

This nonstructural approach specifies the performance equation in terms of an accounting measure of performance; however, the accounting measure was ultimately derived from a

like data envelopment analysis. The nonparametric techniques typically focus on technological optimization rather than economic optimization. Since they generally ignore prices, the nonparametric methods can account only for technical inefficiency in using too many inputs or producing too few outputs and cannot account for allocative inefficiency in which firms inefficiently choose inputs and outputs given their relative prices. 
structural model of banking. Other structural models, as noted above, might include other accounting measures of inefficiency derived directly from a maximum profit function or a minimum cost function fitted as a frontier.

Hughes and Moon (2003) develop a structural model of managerial behavior to explain the market value managers produce and, given their firm's potential value, the market value they fail to produce, a measure of agency costs. Managers' choice of the value they produce and the value they consume as agency goods maximizes their utility. The authors use this framework to derive a utility-maximizing managerial demand function for agency goods (inefficiency) and apply the structural properties of utility-maximizing demand to decompose the effect of ownership changes into substitution and wealth effects.

Many nonstructural models simply begin their specification of equation (1) with either an accounting measure of performance, such as return on assets, return on equity, or the ratio of noninterest expense to total expense, which gauges operating cost efficiency. Alternatively, they may use a measure of performance derived from the market value of assets, such as Tobin's $q$ ratio, the market value of assets divided by the replacement cost of assets. Tobin's $q$ ratio, which is commonly proxied by the market value of equity plus the book value of liabilities divided by the book value of assets, measures how much market value is created from a particular investment in assets. For example, Morck, Shleifer, and Vishny (1988) regress Tobin's $q$ on the proportion of outstanding shares owned by officers and directors to look for evidence that ownership aligns the interests of insiders with those of outside owners.

Hughes, Lang, Moon, and Pagano (1997) proposed using the stochastic frontier technique to measure the highest potential value of banks' assets across all markets in which they operate. This technique was also used in Hughes, Lang, Mester, Moon, and Pagano (2003). The difference between a bank's potential and achieved values, as a proportion of its potential value, represents the bank's market-value efficiency. The stochastic frontier technique eliminates the influence of statistical noise and estimates the systematic failure to achieve potential value. The Appendix describes the technique in more detail.

Other nonstructural models that gauge performance from market value rely on the Sharpe ratio (the ratio of the firm's expected excess return over the risk-free return to the standard deviation of the excess return $\left.=\left(\mathrm{R}-\mathrm{R}_{\mathrm{f}}\right) / \sigma_{\mathrm{R}-\mathrm{Rf}}\right)$ and on event studies, which investigate the response of the market's valuation of banks when an unanticipated event occurs. An asset 
pricing model separates the systematic movement of a stock's price from the unexplained "abnormal" return. Summed over the event window, the cumulative abnormal return, or CAR, is then regressed on factors thought to explain it. For example, Brook, Hendershott, and Lee (1998) considered the reaction of bank stock prices to the passage of the Interstate Banking and Branching Efficiency Act and identified a statistically significant positive CAR. They hypothesized that the act would increase the probability of takeovers for inefficient banks. When they regressed the CAR of each bank in their sample on banks' performance and ownership structure, they found that underperforming banks whose management was least entrenched received the strongest price reaction.

\section{Market discipline, public regulation, and the federal safety net}

Market discipline interacts with banking regulations and supervision to influence the performance of banks and the stability of the banking system. The federal safety net seeks to promote banking system stability. The formal safety net guarantees payments on Fedwire, the large-value payments system, and deposits up to $\$ 250,000$. The informal safety net applied to institutions considered too big to fail provides an implicit guarantee of formally uninsured liabilities of commercial banks. Both the formal and informal safety net implies that depositor and creditor discipline of bank management will be significantly eroded. In addition, to obtain a charter to gain entry into commercial banking markets, a start-up bank must demonstrate that its management is experienced and that it commences operation with adequate capitalization. Limitations on entering commercial banking markets through the chartering process promote bank safety, but they also create market power for banks in some local markets. Market power is especially valuable when markets are experiencing economic growth. These regulatory features of banking, explicit and implicit deposit insurance and restrictions on entry, create contrasting incentives for risk-taking and value maximization. In the case of banks for which high-risk investment strategies maximize shareholder value, market discipline that promotes value maximization can threaten the stability of the banking system.

Marcus (1984) shows that value-maximizing banks face dichotomous incentives for risktaking that result from regulatory limitations on entry and from the mispriced federal safety net. He finds that banks with valuable investment opportunities, say, because they operate with 
market power in growing markets, protect their charters from episodes of financial distress by pursuing relatively less risky investment strategies to maximize the expected value of their assets. On the other hand, banks with less valuable investment opportunities, say, because they operate in very competitive markets, exploit the cost-of-funds subsidy due to implicit and explicit deposit insurance by pursuing relatively more risky investment strategies to maximize the expected value of their assets. For the latter financial institutions, market discipline encourages risk-taking, which may work against financial stability.

Keeley (1990) provides evidence that the liberalization of a number of regulatory restrictions on banking has increased the competition banks face and has caused the value of their charters to fall. In turn, the falling charter values have encouraged bank risk-taking as investment strategies that protect charter value have lost value relative to those that exploit the cost-of-funds subsidy of the federal safety net. Grossman (1992) finds that thrift institutions in the U.S. adopted more risky investment strategies after securing deposit insurance.

Using two measures of financial performance based on the market value of assets, Tobin's $q$ and an efficiency measure equal to the ratio of achieved market value to the potential market value estimated by a stochastic frontier, Hughes, Lang, Moon, and Pagano (1997) find evidence of the dichotomous investment strategies Marcus described. They find that highleverage banks could improve financial performance by lowering equity and low-leverage banks could improve performance by raising their equity ratio. Banks in the third of their sample with the highest capital ratios appear to have exhausted the gains from increasing the capital ratio, while those in the middle third can still improve their $q$ ratio and market value efficiency by increasing the capital ratio. Banks in the lowest third, though, improve their $q$ ratio and market value efficiency by reducing their capital ratio. Banks with lower capital ratios, they find, tend to have lower valued investment opportunities and tend to be larger. Thus, among the larger financial institutions in their sample, value enhancement tends to be associated with riskier investment strategies.

A number of studies find that the most profitable banks before the recent financial crisis, which took more risks, were the least profitable during the crisis when the risks led to unexpected losses (e.g., Beltratti and Stulz, 2009, and Cheng, Hong, and Scheinkman, 2010). These banks tended to be the largest financial institutions, including Bear Stearns, Citigroup, and 
AIG. Is a higher-risk investment strategy in a bank's self-interest? These strategies appear to maximize expected value, which is realized in good economic conditions.

Other important aspects of bank regulation create additional differences between the market discipline of financial and nonfinancial firms. Banks cannot be owned by nonfinancial firms, and mergers of banks are subject to restrictions and must be approved by the Federal Reserve Board. Until the passage of the Interstate Banking and Branching Efficiency Act in 1994, the McFadden Act and the Douglas Amendment of the Bank Holding Company Act had put banks under the branching laws of the state in which they were chartered. Until 1975, states had prevented out-of-state banks from purchasing in-state banks. Beginning in 1975 in Maine and then in 1982 in Massachusetts, states began to relax some of these restrictions in limited ways. The Interstate Banking and Branching Efficiency Act essentially repealed the McFadden Act and the Douglas Amendment to allow banks to merge across state lines. Thus, the passage of this legislation significantly increased the number of potential buyers of a bank in a takeover and increased the takeover threat faced by all but the most entrenched managers. In short, restrictions on ownership of banks, regulatory approval of mergers, and historical restrictions on mergers across state lines have significantly limited the threat of takeover as a disciplining mechanism of management and have meant that other sources of market discipline would be more important in banking. However, with the passage of the Interstate Banking and Branching Efficiency Act in 1994, as Brook, Hendershott, and Lee (1998) show, takeover discipline has improved.

Another important difference in the discipline faced by banks is the regulation and supervision imposed on them by federal and state law. Bank operations are much more thoroughly regulated than most nonfinancial firms. Rather than simply focus on protecting shareholder value, regulation promotes bank safety and soundness. For banks with valuable investment opportunities, such regulation may be in the interests of the shareholders, since lower-risk investment strategies maximize value at these banks. In the case of institutions with poorer investment opportunities, safety and soundness regulation may conflict with the adoption of higher-risk strategies that maximize the value of these banks. The evidence of dichotomous strategies to maximize value found by Hughes, Lang, Moon, and Pagano (1997) suggests that the least levered banks have exploited all the efficiency gains from their capital structure, while the most levered banks have unexploited gains to increasing their leverage further. They 
hypothesize that regulation prevents these banks from doing so. Most of these banks are very large.

Safety and soundness, of course, are enhanced by efficient management, especially of risk. DeYoung, Hughes, and Moon (2001) find evidence in banks' regulatory assessments, their CAMEL ratings, that bank examiners appear to take bank efficiency into account in assigning ratings. Using the risk vs. expected-return frontier developed by Hughes, Lang, Mester, and Moon $(1996,2000)$, they find that regulators treat the risk-taking of efficient banks differently than the risk-taking of inefficient banks and afford efficient banks more latitude in their investment strategies than inefficient banks. While their U.S. data are drawn from 1994 and may not shed much light on the years preceding the crisis that began in 2007, they do suggest that supervisors hold large inefficient banks (i.e., banks whose safety and soundness is most likely to have implications for the stability of the banking system) to higher standards than large efficient banks.

Barth, Caprio, and Levine (2004 and 2006) provide comprehensive studies of banks in 107 countries and in over 150 banks, respectively, which assess the relationship between several aspects of bank regulation and supervision and bank performance, efficiency, and stability. The authors surveyed the banks in 2003-2004 and created a large database chronicling multiple aspects of bank regulation, supervision, structure, and performance. The general conclusion from these studies is that market-based discipline, as opposed to government supervision, results in better banking performance along a variety of dimensions.

Other cross-country studies include Pasiouras (2008), Pasiouras, Tanna, and Zopounidis (2009), Delis, Moyneux, and Pasiouras (2011), and Chortareas, Girardone, and Ventouri (forthcoming). These studies generally support the finding that market discipline can improve bank performance, although there are mixed results on whether certain forms of supervision and regulations, e.g., capital requirements or restrictions on bank activities, do. Using the survey data from Barth, Caprio, and Levine (2006), Pasiouras (2008) studies the relationship between bank efficiency and bank supervision and regulation using a sample of 715 banks in 95 countries. He estimates technical and scale efficiency using data envelopment analysis and then performs Tobit regressions of efficiency on measures of regulations related to capital adequacy, the degree of private monitoring, bank activities, deposit insurance, the power of banking authorities to discipline banks, and entry restrictions. Private monitoring is measured by an index that 
indicates the degree to which information is released to officials and the public, the extent of auditing requirements, and whether credit ratings are required. He finds that a higher level of private monitoring is significantly positively related to bank efficiency across all specifications; the other regulatory characteristics are less robust across specifications. Pasiouras, Tanna, and Zopounidis (2009) also investigate the relationship between bank efficiency and regulation using data on a sample of 615 publicly traded commercial banks operating in 74 countries during 2000-2004. Profit and cost efficiency are measured using stochastic frontier analysis. The results indicate that higher market discipline and greater supervisory power are significantly positively related to both profit and cost efficiency, while stricter capital requirements are positively related to cost efficiency and negatively related to profit efficiency, and restrictions on bank activities are negatively related to cost efficiency and positively related to profit efficiency. Delis, Molyneux, and Pasiouras (2011) investigate the relationship between bank productivity growth and supervision and regulation using data on 582 commercial banks in 22 transition countries, including those in the former Soviet Union and others in eastern Europe during 19992009. They find that productivity growth is significantly positively related to regulations and incentives that promote private monitoring and to restrictions on bank activities, but not significantly related to capital adequacy requirements or official supervisory power. Chortareas, Girardone, and Ventouri (forthcoming) study the relationship between bank efficiency, measured using data envelopment analysis, and supervision and regulation using data on banks in 22 countries in the European Union over 2000-2008. The number of banks included in the sample varies over the years, from a low of 472 to a high of 704 . In contrast to the other studies, this paper finds that a higher degree of private monitoring is related to lower efficiency. It also finds that tighter capital requirements and stronger official supervisory powers are positively related to efficiency, whereas restrictions on activities are negatively related to efficiency.

\section{Sources of market discipline}

\subsection{Ownership Structure}

When managers of a firm trade a dollar of firm value for personal benefits such as avoiding effort and consuming perquisites, the cost to them of the dollar of benefits is determined by their ownership stake in the company. If they own 10 percent, the dollar of personal benefits costs them 10 cents, while outside owners bear 90 cents of the costs. Jensen 
and Meckling (1976) hypothesized that as the ownership stake of insiders increases, their interests are better aligned with those of outside owners and that agency costs are reduced. They define the firm entirely owned by its manager as the zero-agency-cost case - where there is no principal-agent problem. They define agency cost as the value lost when the owner-manager sells part of the firm to an outsider so that the cost of a dollar of personal benefits is now less than a dollar. Ang, Cole, and Lin (2000) use data on small- to medium-sized businesses in the U.S. where there are a number of firms that are entirely owned by their managers. They compare various measures of financial performance for these firms with firms where outsiders share in the ownership of the firm. In the limiting case, the primary manager owns none of the firm. They find that a higher ownership stake by managers is associated with improved performance.

Morck, Shleifer, and Vishny (1988) allow for the possibility that as the ownership stake of insiders increases, their ability to resist various forms of market discipline increases: managers become entrenched. Thus, an increasing level of insider ownership not only increases the price of consuming agency goods, which tends to align insiders' interests with those of outside owners, it also increases insiders' control. The relationship of value to insider ownership depends, then, on the relative strength of the alignment-of-interest effect vs. the entrenchment effect. Applying a piecewise linear specification of the proportion of the firm owned by officers and directors to data on nonfinancial firms in the U.S., the authors find a statistically significant positive relationship between Tobin's $q$ ratio and insider ownership between 0 and 5 percent ownership, a statistically significant negative relationship between 5 and 25 percent, and a less significant, positive relationship at ownership exceeding 25 percent. They interpret alignment as dominant at less than 5 percent and greater than 25 percent and entrenchment as dominant in range of 5 to 25 percent. They note that Weston (1979) found that no firm where insiders owned more than 30 percent of the firm had ever been acquired in a hostile takeover. Weston suggested that the ability of insiders to resist a hostile bid occurs in the ownership range of 20 to 30 percent. Morck, Shleifer, and Vishny's finding that entrenchment dominates alignment in the range 5 to 25 percent suggests that a firm's ability to resist market discipline may begin at a much lower range of insider ownership.

Gorton and Rosen (1995) use annual call report data on banks for the period 1984-1990 and find that managerial entrenchment and corporate control issues played a more important role than the moral hazard related to mispriced deposit insurance in explaining the increased risk- 
taking in banking in the 1980s. They find a nonlinear relationship between insider ownership, managerial entrenchment, and bank risk-taking. As they show, the relationship between ownership and control is a complicated one - as the degree of stock ownership by managers increases it can increase their ability to act on their own behalf rather than aligning their incentives with the majority shareholders. However, that relationship also depends on how healthy the industry is, i.e., on the degree of investment opportunities. When investment opportunities are low, managers may be induced to take on more risk because conservative behavior may not be enough to allow them to keep their jobs and perquisites in a declining industry.

Using data on small, closely held U.S. banks in the Tenth Federal Reserve District to study the relationship of performance to ownership, DeYoung, Spong, and Sullivan (2001) note that since these banks are not actively traded, the discipline of the market for corporate control is largely lacking. In addition, outside owners generally are few in number and hold a relative small stake in the company. Consequently, they have little incentive to monitor. The primary owners who are not managing the bank and whose stake is large enough to monitor may lack the skills and inclination to monitor, especially when they have retired from managing the bank or turned to hired managers as the bank's operations grew and became more complex. The authors estimate a stochastic profit frontier to gauge efficiency - achieved profit as a proportion of bestpractice potential profit. They estimate the performance equation (1) by regressing profit efficiency on ownership structure and control variables. Rather than specify piecewise continuous insider ownership variables as in Morck, Shleifer, and Vishny (1988), they use a quadratic specification - insider ownership and the square of insider ownership. They find that hired managers are on average slightly more efficient than owner managers. The proportion of the bank owned by the owner manager is not statistically significantly related to the bank's performance, while the proportion owned by the hired manager is significantly positively related to profit efficiency up to 17 percent insider ownership and is then significantly negatively related. Thus, at less than 17 percent, the alignment effect of ownership dominates the entrenchment effect, and at greater than 17 percent, entrenchment dominates. Most of the banks in their sample with hired managers provide them with less than 17 percent ownership. The quadratic specification of insider ownership has an important advantage over the piecewise linear specification: the quadratic is more flexible in that it does not impose the breakpoints between 
shifts in slopes. However, without a cubic specification, one cannot investigate whether at a higher ownership stake, greater than 25 percent in the case of Morck, Shleifer, and Vishny (1988), the alignment effect once again dominates entrenchment.

To consider the possibility that the sign of the relationship between performance and insider ownership changes three times in the bank data and to allow the data to show where these breaks occur, we use the data of Hughes, Lang, Mester, Moon, and Pagano (2003). The sample is all publicly traded, top-tier bank holding companies in 1993 and 1994; there are 169 of these firms. Performance is measured by market-value inefficiency, derived from a market value frontier and gauging the difference between the achieved market value of assets and the bestpractice potential value (the shortfall) as a proportion of potential value. We measure the proportion of outstanding shares owned by officers and directors in the year before, i.e., in 1993, and market-value inefficiency at the end of 1994. This attempts to control for the endogeneity of ownership, although admittedly this may not be adequate as ownership does not change very much over time. We control for the size of banks as indicated by the natural log of total assets. Managers of larger banks typically own a smaller proportion because the wealth needed to own large proportions is too great. We also control for the value of a bank's investment opportunities. Managers with much more valuable investment opportunities are, on average, much less efficient - they achieve a smaller proportion of their potential value - than those with poorer investment opportunities, even though both groups have essentially the same average $q$ ratio. The value of a bank's investment opportunities is measured by fitting a stochastic frontier to the market value of assets as a function of the book value of assets and, in the bank's local markets, the market-weighted, 10-year average macroeconomic growth rate and marketweighted Herfindahl index of concentration. A bank's investment opportunity index is the bestpractice market value of the bank's assets in the local markets in which it operates as a proportion of its book-value investment in assets. Insider ownership is the proportion of the firm owned by officers and directors.

Table 1 provides summary statistics for the full sample of 169 publicly traded, top-tier bank holding companies in 1994, and for the more efficient and less efficient halves of the sample, where we gauge performance by the market-value inefficiency measure. (These statistics are also reported in Hughes, Lang, Mester, Moon, and Pagano, 2003). As shown in Panel A, the bank holding companies in the full sample range in size from $\$ 159.86$ million to 
$\$ 211.764$ billion in assets. The market-value inefficiency ratio indicates that, on average, banks fail to achieve 19.1 percent of their potential market value while their average $q$ ratio is 1.036 . Their mean potential value in the markets in which they operate as a proportion of their bookvalue investment in assets is 1.073 .

As shown in Panels B and C, the more efficient half of the sample holds more total assets and their insiders own less of their banks than the less efficient half. Their lower ownership stake may result from the very large size of the banks they manage. The more efficient half of the sample exhibits more outside blockholder ownership, which may contribute to their efficiency through their greater ownership incentive to monitor the performance of insiders. However, the more efficient half also holds proportionately less capital. It is not clear the extent to which better diversification and increased risk-taking may contribute to the lower capital ratio.

The potential value of investment opportunities for less efficient banks as a proportion of their book-value investment in assets far exceeds that of the more efficient banks: 1.110 versus 1.037. Recall that a bank's market-value efficiency is measured by the achieved market value of its assets as a proportion of its potential value measured across all markets - not just the markets in which it operates. The less efficient half of the banks in the sample on average waste 33.8 percent of their potential value, while the more efficient half waste only 6 percent on average. However, their average $q$ ratios are identical. The $q$ ratio fails to capture the stark difference in performance between these two groups of banks. The stochastic frontier technique identifies the critical difference in the value of investment opportunities between the two groups of banks and, when used to calculate lost market value, shows that banks with more valuable investment opportunities tend to waste more value than banks with poorer opportunities.

These contrasts between the more efficient and less efficient banks suggest that differences in asset size and the value of investment opportunities play an important role in shaping managerial performance incentives (which is consistent with Gorton and Rosen, 1995). Hence, we use the natural logarithm of total assets and the investment opportunity ratio as control variables in our performance regressions.

Table 2 shows the ordinary least squares estimates of a regression of market-value inefficiency on the cubic specification of insider ownership and the control variables, $\ln$ (asset size) and the investment opportunity ratio. Over the range of insider ownership between 0 and 15.6 percent, market-value inefficiency is significantly negatively related to insider ownership; 
hence, alignment dominates entrenchment. Over the range 15.6 to 49.7 percent, market-value inefficiency is positively related to insider ownership so that entrenchment dominates alignment. Above 49.7 percent, the relationship becomes negative so that alignment again dominates. While the derivative of market-value inefficiency is significantly negative in this region, there are only five banks with ownership greater than 49.7 percent (66 percent is the highest stake).

These results are similar to those of DeYoung, Spong, and Sullivan (2001) where the positive relationship between performance and insider ownership changes to a negative relationship at 17 percent; however, the results here differ in that we allow the data to reveal a third regime where the sign of this relationship changes again. In that sense, these results are qualitatively similar to those of Morck, Shleifer, and Vishny (1988); however, the quantitative values of the two turning points for the sign of the relationship of performance to insider ownership for commercial banks differ significantly from those Morck, Shleifer, and Vishny (1988) found by trial and error for nonfinancial firms.

The statistically significant negative coefficient on asset size indicates that larger banks on average achieve more of their best-practice value than smaller banks, and the statistically significant positive coefficient on the investment opportunity ratio indicates that banks with more growth opportunities waste more of this value than those with poorer opportunities.

Large holdings of shares provide another perspective on the relationship of performance to ownership, especially when the large shareholder is unrelated to management (e.g., an outside blockholder). A blockholder is defined as a holder of 5 percent or more of outstanding shares based on 13D filings. Large blocks of stock ownership give their owners a substantial financial stake in the firm, large enough to overcome the free-rider problem of small stakeholders and to monitor managers' performance or perform better when part of management. Holderness (2003) calls the hypothesis that blockholders either monitor insiders better or, when they are insiders themselves, perform better the shared benefits hypothesis. On the other hand, blockholders can use their voting power to consume pecuniary and nonpecuniary private benefits of control. Holderness terms this possibility the private benefits hypothesis. While the consumption of private benefits by blockholders might be thought to influence firm value negatively, it might also be positive. According to Holderness, the impact of blockholders on firm value has not been firmly established as either positive or negative, and there is little evidence that it has a large effect whatever the sign. 
Outside blockholders are thought to be more independent of management and, therefore, better able to monitor and positively influence performance. We consider the relationship of bank performance and ownership by outside blockholders by regressing market-value inefficiency on a quadratic specification of the proportion of the firm owned by outside blockholders to allow for a nonmonotonic relationship that could capture both the shared and private benefits hypotheses at different levels of ownership. ${ }^{4}$ We control for the value of a bank's investment opportunities with the investment opportunity ratio and its size with the log of the value of its assets. Table 3 reports the results of this regression. The positive coefficient on the linear term, 0.00256, and the negative coefficient on the squared term, -0.00006618 , reveal that the positive sign of the derivative of market-value inefficiency with respect to blockholder ownership changes to a negative sign at the level of 19.3 percent blockholder ownership. Thus, at levels smaller than 19.3 percent, increasing blockholder ownership is associated with higher inefficiency, a result consistent with the private benefits hypothesis. However, at levels above 19.3 percent, where the opportunity cost of consuming private benefits may be too high, increasing blockholder ownership is associated with lower inefficiency, a result consistent with the shared benefits hypothesis; however, the value of the derivative is not statistically significant in these cases. ${ }^{5}$ Again, the negative coefficient on size indicates that larger banks are more efficient, and the positive coefficient on the value of investment opportunities indicates that banks in more valuable markets are less efficient.

The commonly used measure of aggregate blockholder ownership lacks details on the type of blockholders represented in the data. Their identity could be important because the seriousness of incentive misalignments within the block may vary by the type of blockholder ownership. Cronqvist and Fahlenbrach (2009) construct a detailed panel data set over the period 1996-2001 that includes all blockholders of 1,919 publicly traded corporations. The data allow the specification, not just of time and firm fixed effects, but also of unique blockholder fixed

\footnotetext{
${ }^{4}$ In our data set there are 118 firms in which there is no blockholder ownership and 51 firms with positive blockholder ownership.

${ }^{5}$ The value of the derivative is significant at the 5 percent level for blockholder ownership values greater than 2.4 percent and less than or equal to 11.8 percent; it is significant at the 10 percent level for blockholder ownership values less than 2.4 percent and for values greater than 11.8 percent and less than or equal to 13.1 percent. There are six observations in the data set for which blockholder ownership is greater than 13.1 percent and less than 19.3 percent; for these observations the derivative is positive but insignificant. There are six observations in the data set for which blockholder ownership is greater than 19.3 percent; for these observations the derivative is negative but insignificant.
} 
effects. They consider how the individual blockholder ownership and type of blockholder are related to various corporate policies and firm performance. They find statistically and economically significant blockholder fixed effects in investment, financial, and compensation policies, which are related to firm performance. On the question of influence versus selection, for activist, pension fund, corporate, individual, and private equity blockholders, they find evidence consistent with influence. But, for large mutual funds, they find evidence consistent with systematic selection. Moreover, their results bear on the incentives of managers of large financial firms that took significant risks leading up to the recent financial crisis. In particular, they find higher return on assets and the $q$ ratio in firms with large shareholders that had aggressive investment styles (including higher levels of investment and M\&A activity). They also find that blockholders that are associated with higher total CEO compensation have more aggressive investment styles, higher investment-to- $q$ sensitivity, and fewer diversifying acquisitions.

Cheng, Hong, and Scheinkman (2010) examine risk-taking and executive compensation at financial institutions - banks, insurance companies, and primary dealers - for the period 19922008 and find that risk-taking and high executive compensation are strongly positively related to institutional ownership. This suggests that institutional investors want these firms to take more risk (perhaps because of shorter horizons due to agency issues) and give them short-term incentives via compensation to do so.

Ellul and Yerramilli (2011) examine the 74 largest publicly listed U.S. bank holding companies in a panel spanning the period 2000-2008 and find that a strong risk-management function is associated with lower future risk and better future financial performance. However, institutions with high institutional ownership were found to exhibit more volatile stock returns.

Laeven and Levine (2009) posit three key hypotheses that they use to examine the relationship of bank risk-taking, ownership structure, and regulatory policies. First, they assert that owners whose stake in a financial institution is a relatively small part of their diversified wealth holdings generally prefer that the institution take more risk than is preferred by debtholders and nonshareholder managers who may avoid risk to protect their relatively undiversified human capital and their private benefits of control. Second, regulations create risk-taking incentives for diversified owners that differ from those of debt-holders and nonshareholder managers. In particular, while deposit insurance may give nonshareholder managers little 
incentive to threaten their control by taking extra risk, diversified equity holders may prefer extra risk-taking when exploiting the subsidy of mispriced deposit insurance. Third, ownership structure affects the ability of owners to influence risk-taking. Larger cash-flow and voting rights give owners greater risk-taking incentives - both the standard risk-shifting incentives and those created by regulations - and greater ability to influence managerial risk-taking policies.

Laeven and Levine (2009) collect data on the 10 largest publicly listed banks in 2001 in each of 48 countries, which because of limits on data availability, results in a sample of 279 banks once state-owned banks are eliminated. The resulting sample accounts for over 80 percent of the assets in each country. The authors consider the relationship of the z-score, a measure of the distance of the bank from insolvency, to various regulatory policies. They create a capital stringency index that measures the degree of regulatory oversight of bank capital and find that the z-score is significantly positively related to the capital stringency index. However, the coefficient on a term that interacts capital stringency with the proportion of cash-flow rights of the largest shareholder is significantly negative. As cash-flow rights become more concentrated, the sign of the relationship of the z-score and capital stringency reverses. In other words, more stringent oversight of bank capital becomes less effective at stabilizing a bank when the bank has a large owner, and with a sufficiently large owner, more stringent oversight of capital regulations increases bank risk. As predicted by Koehn and Santomero (1980), the intensification of capital regulation provides diversified bank equity holders with the incentive to adopt more risky investment for higher expected return to compensate for expected return lost to stricter capital regulation.

Countries often attempt to enhance bank stability by imposing activity restrictions. Laeven and Levine (2009) create an index of activity restrictions and find a statistically significant negative relationship of bank stability to the interaction of the index with the cashflow rights of the largest shareholder. When banks in a country are widely held, there is no statistically significant relationship of bank stability and activity restrictions; however, when bank ownership is concentrated, activity restrictions are associated with more risky investment strategies and less stable banks. They also find evidence that the moral hazard effect of deposit insurance appears when there is concentrated ownership but not when ownership is diffuse. ${ }^{6}$

\footnotetext{
${ }^{6}$ When bank stability is regressed on a variable that indicates whether there is explicit deposit insurance or the complete guarantee of losses in the last banking crisis, its coefficient is significantly negative. However, when the
} 


\subsection{Capital markets}

The threat of a takeover provides management with a strong incentive to perform efficiently. As noted above, the regulation of banking markets has historically limited takeovers. Notably, until the passage of the Interstate Banking and Branching Efficiency Act of 1994, states in the U.S. limited entry into their banking markets by out-of-state banks. Schranz (1993) uses differences in entry restrictions across states to investigate how these differences in takeover threat, controlling for other sources of managerial discipline, are related to banking performance. Banks in states with an active takeover market are more profitable. On the cost side, Evanoff and Örs (2002) find that entry into local banking markets leads to improved cost efficiency among incumbent banks.

Brook, Hendershott, and Lee (1998) use the event-study method to consider how banking stock prices responded to the passage of the Interstate Banking and Branching Efficiency Act. They find a statistically significant positive cumulative abnormal return to the industry. Poorer performing banks prior to the passage of the act obtain the largest abnormal returns, limited only by evidence of entrenched management.

Hughes, Lang, Mester, Moon, and Pagano (2003) find evidence of managerial entrenchment at U.S. bank holding companies that have higher levels of managerial ownership, higher valued investment opportunities, poorer financial performance, and smaller asset holdings. At banks that do not exhibit signs of managerial entrenchment, asset sales and acquisitions are both associated with improved financial performance; however, at banks with entrenched management, only asset sales lead to improved performance. This suggests that entrenched managers may engage in empire building to feather their own nests at the expense of shareholders.

\subsection{Product markets}

John Hicks (1935, p.8) famously noted, "The best of all monopoly profits is a quiet life." The quiet life is not an automatic benefit of market power since the many other disciplining mechanisms of management are not short-circuited by market concentration. Berger and Hannan (1998) control for these other sources of discipline and find evidence that market concentration is negatively related to operating cost efficiency in U.S. banking. As noted previously, Evanoff

regression also includes an interaction term between this deposit insurance variable and the cash-flow rights of the largest shareholder, the deposit insurance variable is not statistically significant, but the coefficient on the interaction term is negative and statistically significant. 
and Örs (2002) find that entry into local banking markets leads to improved cost efficiency among incumbent banks.

In contrast to these papers, Petersen and Rajan (1995) find a benefit to concentration in banking markets that flows from banks' special information about their depositors obtained from their deposit records, which allows banks to make information intensive loans to relatively opaque borrowers more efficiently than nondepository lenders. With this information, banks are able to lend at a lower interest rate to young firms to reduce their probability of financial distress in the early years of their operation. However, banks must recover the cost of these subsidies in the later years of these lending relationships. In competitive markets the ability of banks to price loans in this manner is limited. In the later years, competitors would take the lending business from banks that tried to recover their earlier subsidies.

We again use the data of Hughes, Lang, Mester, Moon, and Pagano (2003) - publicly traded, top-tier banking holding companies in 1993 and 1994 - to investigate the relationship between performance and concentration. We measure a bank holding company's market power by a Herfindahl index constructed as the weighted sum of the bank holding company's squared share of deposits in each of its local markets, where the weights are the proportion of total deposits found in each market. Higher values imply the bank holding company has more market power in its markets. The performance measure, market-value inefficiency, is derived from a market-value frontier and is the difference between the best-practice potential (frontier) value and the noise-adjusted observed market value of assets, as a proportion of the potential value. Table 4 reports, as in previous regressions, a larger asset size is related to lower inefficiency, while having more valuable investment opportunities is related to greater inefficiency. The coefficients on the Herfindahl index, -0.28964 , and on the squared index, 0.37171 , imply that at degrees of market concentration below 0.39 , concentration and inefficiency are negatively related, which is consistent with the Petersen-Rajan hypothesis. Above this value, the relationship switches signs so that higher concentration is positively related to higher inefficiency, which is consistent with the quiet-life hypothesis and the increasing ability of banks to extract surplus as concentration increases. While the regression reported in Table 4 controls for the value of investment opportunities, which results in part from market power, it does not control for prices charged on loans and paid on borrowed funds. Hence, we add these interest rates as control variables and report the results in Table 5. 
The statistically significant negative coefficient on the Herfindhal index, -0.23524 , and the positive coefficient on the squared index, 0.30791, again imply that the negative value of the derivative of inefficiency with respect to market concentration switches to a positive value - in this case, at 0.382 . While controlling for prices reduces the sensitivity of inefficiency to concentration, it does not fundamentally change the nonmonotonic relationship.

\subsection{Labor markets}

The financial crisis that began in 2007 has called into question the performance of many managers. Does the labor market recognize bad managers and punish them? Cannella, Fraser, and Lee (1995) investigate the efficiency of labor markets in banking: they ask if labor markets can distinguish the efficiency of managers from the efficiency of their banks. To answer this question, they consider Texas banking during the troubled period 1985 through 1990 when many banks failed. In particular, they compare matching samples of banks that did not fail with banks that failed because they were insolvent and with banks that, while not insolvent, nevertheless failed because they were part of a multi-bank holding company that failed. The latter group is termed "innocent bystanders" and the former "equity insolvent." They find that 67 percent of managers of nonfailed banks were still employed in 1993 in Texas banking. In contrast, only 22 percent of managers of equity insolvent banks were still employed, while 44 percent of the managers of the innocent bystander banks were employed. In addition, they find that managers of the top-tier bank within the holding company are less likely to find employment in banking after their banks fail than second-tier managers. Finally, they find that managers of nonfailed banks whose cost efficiency measured by the ratio of noninterest expense to total assets is lower are less likely to be employed in Texas banking in 1993. Thus, labor markets appear to distinguish good from bad managers and weed out the latter.

\subsection{Boards of directors}

Boards of directors are charged with oversight of management, hiring and firing the $\mathrm{CEO}$, setting top executive compensation, and providing advice and strategic guidance. Hermalin and Weisbach (2003) and Adams, Hermalin, and Weisbach (2010) survey the theoretical and empirical literature on boards. In carrying out their oversight function, boards require a degree of independence from management. Gauging the effectiveness of oversight often considers the composition of the board in terms of the proportion of the board's members who are independent outsiders - not part of management and not related to management by 
family, by business relationships ("grey" directors), or by interlocking boards. In addition, oversight may be improved when the roles of board chair and CEO are separated - although this need not be the case: recall that Enron had such a separation. In contrast to these arguments for independence of board members and the chair, insiders serving on the board can provide important information for board oversight and strategic decision-making. Similar arguments can be made for combining the roles of CEO and board chair.

Hermalin and Weisbach (2003) note that empirical research on boards typically reaches only two conclusions: the composition of the board and firm performance do not appear related, while the size of the board and performance are usually negatively related. On the other hand, evidence provides a clearer picture of the relationship of board composition to board actions. For example, Core, Holthausen, and Larcker (1999) regress CEO compensation on three sets of variables: economic determinants of optimal compensation and characteristics of ownership structure and board structure. They find that most variables in all three sets are statistically significant, and, in the case of ownership and board structure variables, the signs of the coefficients suggest that higher compensation is correlated with characteristics associated with weaker governance structures. In terms of board structure, higher CEO compensation is associated with larger boards, boards chaired by the CEO, a higher proportion of inside directors, higher proportions of grey and interlocked outside directors, a higher proportion of "busy" outside directors who serve on three or more boards, and outside directors over the age of 69 . To determine whether the influence of board and ownership structure variables on compensation reflects agency problems or correlation with missing economic determinants, future performance is regressed on the portion of compensation predicted by board and ownership structure variables. Since future performance varies inversely with this "excess" compensation, the authors conclude that the higher CEO compensation and poorer future performance reflect agency problems.

Examining data on U.S. banks over the period 1964 to 1989, Adams and Mehran (2008, revised 2011) find that performance measured by Tobin's $q$ is not related to board independence; however, performance is positively related to board size. They speculate that the growing complexity of banks and mergers and acquisitions during this period may account for the result. They test and reject these explanations. Instead, they find that larger boards are associated with increased value when they include a larger number of directors who also sit on subsidiary boards. 
These joint directors apparently facilitate communication among the subsidiaries and parent company.

Tanna, Pasiouras, and Nnadi (2012) examine the relationship between efficiency and board structure of 17 banks operating in the U.K. between 2001 and 2006 and find results that contrast with those of Adams and Mehran for U.S. banks. Tanna, Pasiouras, and Nnadi measure efficiency based on data envelopment analysis techniques. When they control for bank asset size and capitalization, as measured by the equity-to-assets ratio, they find a positive and significant relationship between the share of nonexecutive members on the board (a proxy for board independence) and efficiency. The size of the board is not significantly related to efficiency, once the composition of the board in terms of share of nonexecutive members is controlled for.

\subsection{Compensation}

The board of directors sets top executive compensation and can structure it so that it ameliorates agency problems. However, the board itself, as noted above, may suffer from misaligned incentives and fail to execute optimal pay arrangements. Thus, the consideration of compensation must account not just for optimal structures, but also for structures that result from agency problems. As noted above, Core, Holthausen, and Larcker (1999) regress CEO compensation on three sets of variables, economic determinants of optimal compensation and characteristics of ownership structure and board structure, and find that most variables in all three sets are statistically significant and that the signs of the coefficients on the variables characterizing ownership and board structure suggest that higher compensation is correlated with with weaker governance structures. The negative relationship of future performance with the portion of compensation predicted by the board and ownership structure variables suggests that the higher compensation results from agency problems rather than optimal contracting.

In banking optimal contracting must account for the value of investment opportunities and the subsidy of risk-taking provided by explicit and implicit deposit insurance. Smith and Watts (1992) note that higher valued investment opportunities add complexity to a firm's decision-making and make monitoring of managerial actions and effort by the board more difficult. Using the stochastic frontier technique to estimate the difference between the bestpractice market value and achieved market value of assets - firms' market-value inefficiency Hughes, Lang, Mester, Moon, and Pagano (2003) find that market-value inefficiency is significantly higher for banks with higher valued investment opportunities. As implied by Smith 
and Watts (1992), managers of these banks appear to waste much more potential value than those with lower valued opportunities. Consequently, Smith and Watts (1992) and Gaver and Gaver (1993) contend that incentive-based compensation such as stock and stock options is much more important to firms with valuable investment opportunities as a tool to reduce agency problems and to encourage managers to pursue these opportunities. On the other hand, banks with poorer investment opportunities maximize their expected value by exploiting the cost-of-funds subsidy of deposit insurance through additional risk-taking. Optimal compensation for these banks encourages risk-averse managers to pursue riskier investment strategies.

Houston and James (1995) examine data on U.S. banks during the period 1981 through 1990 and find that banks with more valuable investment opportunities are more likely to rely on equity-based incentives, while banks classified as too big to fail are no more likely to rely on equity-based compensation. They conclude that compensation in banking does not appear to promote risk-taking at banks with low-valued investment opportunities. However, this result is contradicted by Cheng, Hong, and Scheinkman (2010) who regress top executive compensation in the financial industry during two periods, 1992-1994 and 1998-2000, on size and sub-industry classification and use the residuals from the regression to analyze their relationship to risk-taking during the subsequent periods, 1995-2000 and 2001-2008, respectively. High residual compensation firms include Bear Stearns, Lehman, Citicorp, Countrywide, and AIG while low to moderate residuals characterize compensation at JP Morgan Chase, Goldman Sachs, Wells Fargo, and Berkshire Hathaway. Firms with high residuals were associated with higher measures of risk during the subsequent periods. In addition, these firms were also more likely to perform extremely well in the earlier period when the economy prospered and extremely poorly during the financial crisis in the latter period. As the authors put it (p. 4), “ ... the aggressive firms that were yesterday's heroes when the stock market did well can easily be today's outcasts when fortunes reverse ..." Examining the structure of compensation, they find that bonuses and equity based compensation (including options) are strongly correlated with risk-taking even controlling for insider ownership. Moreover, residual compensation and risk-taking are positively correlated with institutional ownership. They conclude that institutional investors appear to prefer higher risk strategies and compensation structures that reward risk-taking. In good times, these strategies result in extremely strong performance. Similarly, Fahlenbrach and Stulz (2011) find that banks whose CEOs enjoyed stronger equity-based performance incentives 
performed significantly worse during the crisis than banks whose CEOs had weaker incentives. Of course, the incentives were designed to create much higher than average expected performance, which would likely have been realized under good macroeconomic conditions.

\section{Conclusions}

In an interesting paper McConnell and Servaes (1995) allude to what they call the two faces of debt. This refers to a dichotomy in how debt influences performance in nonfinancial firms. For firms with valuable investment opportunities, debt creates underinvestment problems; thus, relatively low financial leverage maximizes value, while for firms with poorer investment opportunities, debt resolves overinvestment problems by imposing performance pressure on managers, so for these firms relatively high leverage maximizes value.

In our view, capital structure in banking also displays two faces, which result from entry restrictions and from the federal safety net. One face looks toward protecting the valuable charter and its associated investment opportunities by adopting relatively low leverage. The other face turns to risk-taking opportunities involving higher leverage that maximize expected value by exploiting deposit insurance and the too-big-to-fail doctrine. One face encourages investment strategies that promote the stability of the financial system; the other face leans toward strategies that can undermine stability in difficult macroeconomic conditions.

The charter gives a bank located in markets with valuable growth opportunities a claim on them that is partially protected from entry by other banks. The charter also provides access to the federal safety net; however, such banks typically adopt low-risk investment strategies that include substantial capitalization to protect the charter from episodes of financial distress that could lead to its loss. These strategies maximize expected value and promote the stability of the financial system. These banks do not exploit the safety net, since the associated risk would erode their expected value. On the other hand, the balance between protecting the charter versus exploiting the safety net shifts for banks located in markets with poorer growth opportunities perhaps because these markets are extremely competitive. For these banks, lower capitalization and investment strategies that are higher risk maximize expected value.

Thus, good governance defined by its goal of aligning the interests of management with outside owners also has two faces. In cases in which maximizing shareholder value results in the 
socially optimal level of risk-taking, it fosters financial stability. But in cases in which maximizing shareholder value results in excessive risk-taking, it requires attention from regulation and supervision. 


\section{References}

Adams, R.B., Hermalin, B.E. \& Weisbach, M. S. (2010) The role of boards of directors in corporate governance: a conceptual framework and survey. Journal of Economic Literature 48, 58-107.

Adams, R.B. \& Mehran, H. (2008, revised 2011) Corporate performance, board structure, and their determinants in the banking industry. Federal Reserve Bank of New York Staff Reports, no. 330.

Ang, J.S., Cole, R.A. \& Lin, J.W. (2000) Agency costs and ownership structure. Journal of Finance 55, 81-106.

Barth, J.R., Caprio, Jr., G. \& Levine, R. (2004) Bank regulation and supervision: what works best? Journal of Financial Intermediation 13, 205-248.

Barth, J.R., Caprio, Jr., G. \& Levine, R. (2006) Rethinking Bank Regulation: Till Angels Govern. Cambridge University Press, Cambridge, MA.

Bauer, Paul W. (1990) Recent developments in the econometric estimation of frontiers. Journal of Econometrics 46, 39-56.

Beltratti, A. \& Stulz, R.M. (2009) Why did some banks perform better during the credit crisis? a cross-country study of the impact of governance and regulation. European Corporate Governance Institute, Finance Working Paper 254/2009.

Berger, A.N. \& Hannan, T.H. (1998) The efficiency cost of market power in the banking industry: a test of the 'quiet life' and related hypotheses. Review of Economics and Statistics, 80, 454-465. 
Berger, A.N. \& Mester, L.J. (1997) Inside the black box: what explains differences in the efficiencies of financial institutions? Journal of Banking and Finance, 895-947.

Brook, Y., Hendershott, R. \& Lee, D. (1998) The gains from takeover deregulation: evidence from the end of interstate banking restrictions. Journal of Finance 53, 2185-2204.

Cannella, Jr., A.A., Fraser, D.R. \& Lee, D.S. (1995) Firm failure and managerial labor markets: evidence from Texas banking. Journal of Financial Economics 38, 185-210.

Cheng, I.-H., Hong, H. \& Scheinkman, J.A. (2010) Yesterday's heroes: compensation and creative risk-taking. NBER Working Paper 16176.

Chortareas, G.E., Girardone, C. \& Ventouri, A. (forthcoming) Bank supervision, regulation, and efficiency: evidence from the European Union. Journal of Financial Stability.

Core, J.E., Holthausen, R.W. \& Larcker, D.F. (1999) Corporate governance, chief executive officer compensation, and firm performance. Journal of Financial Economics 51, 371-406.

Cronqvist, H. \& Fahlenbrach, R. (2009) Large shareholders and corporate policies. Review of Financial Studies 22, 3941-3976.

Delis, M.D., Molyneux, P. \& Pasiouras, F. (2011) Regulations and productivity growth in banking: evidence from transition economies. Journal of Money, Credit, and Banking 43, 735764.

DeYoung, R.E., Hughes, J.P. \& Moon, C.-G. (2001) Efficient risk-taking and regulatory covenant enforcement in a deregulated banking industry. Journal of Economics and Business, $53,255-282$. 
DeYoung, R., Spong, K. \& Sullivan, R.J. (2001) Who's minding the store? motivating and monitoring hired managers at small, closely held commercial banks. Journal of Banking and Finance 25, 1209-1243.

Ellul, A. \& Yerramilli, V. (2011) Stronger risk controls, lower risk: evidence from U.S. bank holding companies. Indiana University Working Paper.

Evanoff, D.D. \& Örs, E. (2002) Local market consolidation and bank productive efficiency. Federal Reserve Bank of Chicago Working Paper 2002-25.

Fahlenbrach, R. \& Stulz, R.M. (2011) Bank CEO compensation and the credit crisis. Journal of Financial Economics 99, 11-26.

Fama, E.F. \& Jensen, M.C. (1983) Separation of ownership and control. Journal of Law and Economics 26, 301-325.

Gaver, J.J. \& Gaver, K.M. (1993) Additional evidence on the association between the investment opportunity set and corporate financing, dividend, and compensation policies. Journal of Accounting and Economics 16, 125-160.

Gorton, G. \& Rosen, R. (1995) Corporate control, portfolio choice, and the decline of banking. Journal of Finance 50, 1377-1420.

Grossman, R.S. (1992) Deposit insurance, regulations, and moral hazard in the thrift industry: evidence from the 1930s. American Economic Review 82, 800-821.

Hermalin, B.E. \& Weisbach, M.S. (2003) Boards of directors as an endogenously determined institution: a survey of the economic literature," Federal Reserve Bank of New York Economic Policy Review 9, 7-26. 
Hicks, J.R. (1935) Annual survey of economic theory: the theory of monopoly, Econometrica 3, $1-20$.

Holderness, C.G. (2003) A survey of blockholders and corporate control. Federal Reserve Bank of New York, Economic Policy Review 9, 51-64.

Houston, J. \& James, C. (1995) CEO compensation and bank risk: is compensation in banking structured to promote risk taking? Journal of Monetary Economics 36, 405-431.

Hughes, J.P. (2011) Syllabus: Economics 408 Market Discipline, http://economics.rutgers.edu/ people/faculty/218-hughes-joseph-p.

Hughes, J.P., Lang, W., Mester, L.J. \& Moon C.-G. (1996) Efficient banking under interstate Branching. Journal of Money, Credit, and Banking 28, 1045-1071.

Hughes, J.P., Lang, W., Mester, L.J. \& Moon C.-G. (2000) Recovering risky technologies using the almost ideal demand system: an application to U.S. banking. Journal of Financial Services Research 18, 5-27.

Hughes, J.P., Lang, W., Mester, L.J., Moon C.-G. \& Pagano, M. (2003) Do bankers sacrifice value to build empires? Managerial incentives, industry consolidation, and financial performance, Journal of Banking and Finance 27, 417-447.

Hughes, J.P., Lang, W., Moon C.-G. \& Pagano, M. (1997) Measuring the efficiency of capital allocation in commercial banking. Federal Reserve Bank of Philadelphia Working Paper No. 982 (revised as Rutgers University Economics Department Working Paper 2004-1).

Hughes, J.P. \& Mester, L.J. (2010) Efficiency in banking: theory, practice, and evidence. In: Berger, A.N., Molyneux, P. \& Wilson, J. (eds.) The Oxford Handbook of Banking, Oxford University Press, pp. 463-485. 
Hughes, J.P. \& Mester, L.J. (2011) Who said large banks don't experience scale economies? evidence from a risk-return-driven cost function," Wharton Financial Institutions Working Paper \#11-47 and Federal Reserve Bank of Philadelphia Working Paper No. 11-27.

Hughes, J.P., Mester, L.J. \& Moon C.-G. (2001) Are scale economies in banking elusive or illusive? Evidence obtained by incorporating capital structure and risk-taking into models of bank production. Journal of Banking and Finance 25, 2169-2208.

Hughes, J.P. \& Moon C.-G. (2003) Estimating managers' utility-maximizing demand for agency goods. Department of Economics, Rutgers University Working Paper 2003-24.

Jensen, M.C. \& Meckling, W.H. (1976) Theory of the firm: managerial behavior, agency costs, and ownership structure. Journal of Financial Economics 5, 305-360.

Jondrow, J., Lovell, C.A.K., Materov, I.S., \& Schmidt, P. (1982) On the estimation of technical efficiency in the stochastic frontier production function model. Journal of Econometrics 19, 233238.

Keeley, M.C. (1990) Deposit insurance, risk, and market power in banking. American Economic Review 80, 1183-1200.

Koehn, M. \& Santomero, A. (1980) Regulation of bank capital and portfolio risk. Journal of Finance. 35, 1235-1244.

Laeven, L. \& Levine, R. (2009) Bank governance, regulation and risk taking. Journal of Financial Economics 93, 259-275.

Marcus, A.J. (1984) Deregulation and bank financial policy. Journal of Banking and Finance 8, $557-565$. 
McConnell, J.J. \& Servaes, H. (1995) Equity ownership and the two faces of debt. Journal of Financial Economics 39, 131-157.

Morck, R., Shleifer, R.M. \& Vishny, R.W. (1988) Management ownership and market valuation: an empirical analysis. Journal of Financial Economics 20, 293-316.

Nakamoto, M. \& Wighton, D. (2007) Citigroup chief stays bullish on buy-outs. Financial Times, July 9, 2009.

Pasiouras, F. (2008) International evidence on the impact of regulations and supervision on banks' technical efficiency: an application of two-stage data envelopment analysis. Review of Quantitative Finance and Accounting 30, 187-223.

Pasiouras, F., Tanna S. \& Zopounidis C. (2009) The impact of banking regulations on banks' cost and profit efficiency: cross-country evidence. International Review of Financial Analysis 18, 294-302.

Petersen, M.A. \& Rajan, R.G. (1995) The effect of credit market competition on lending relationships. Quarterly Journal of Economics 110, 407-443.

Schranz, M.S. (1993) Takeovers improve firm performance: evidence from the banking Industry. Journal of Political Economy 101, 299-326.

Smith, C.W. \& Watts, R.L. (1992) The investment opportunity set and corporate financing, dividend, and compensation policies. Journal of Financial Economics 32, 263-292.

Tanna, S., Pasiouras, F. \& Nnadi, M. (forthcoming in 2012) The effect of board size and composition on the efficiency of U.K. banks. International Journal of the Economics of Business.

Weston, J.F. (1979) The tender takeover. Mergers and Acquisitions, 74-82. 


\section{Appendix. Measuring performance based on the highest potential market value of assets}

The market value of a firm's assets captures several aspects of the firm's performance that cannot be evaluated by accounting measures based on profit and cost. First, the market value represents the market's expectation of current and future profits and costs. In contrast, accounting measures capture the firm's current or historical cash flow. Firms that take more risks expect higher profits. If the firm's additional risk enhances the market value of its assets, the additional expected cash flow more than compensates for the higher required return on assets occasioned by the extra risk. In other words, the discounted expected value of the cash flow increases; therefore, the firm's market value increases. Thus, market value offers two key advantages over accounting measures of performance: it captures a firm's current and future expected cash flow, and it incorporates the market's assessment of the discount rate required by the risks the firm takes.

Tobin's $q$ ratio measures the ratio of the market value of assets to the replacement cost of the assets - the average market value of a dollar investment in assets - and is a commonly used measure of performance based on market value. For example, the classic study of the relationship of managerial ownership to performance by Morck, Shleifer, and Vishny (1988), discussed in Section 3.1, uses a proxy for Tobin's $q$ to gauge performance. The authors find that the $q$ ratio and managerial ownership are correlated even when controlling for firm size. In a firm owned entirely by its management, such a relationship would not be expected, since the agent (manager) is also the principal (owner). However, when some owners have no role in management, this separation of ownership and management can lead to agency problems that vary by the division of ownership between insiders and outsiders; this is consistent with the econometric correlation of managerial ownership and firm performance.

While the $q$ ratio provides evidence consistent with agency problems, it does not gauge the extent of those problems. If it were possible to estimate the highest potential value of a firm's assets given its investment in those assets, the difference between the highest value and the achieved value might provide evidence on the magnitude of agency costs. A more accurate gauge of agency problems would need to eliminate the influence of luck or statistical noise on that difference. One approach for doing this, proposed by Hughes, Lang, Moon, and Pagano (1997) and used by Hughes, Lang, Mester, Moon, and Pagano (2003), is to fit a stochastic frontier (an upper envelope) of firms' market values to the firms' investment in assets, which is a 
statistical technique for separately estimating the firms' best-practice market value given investment in assets, the systematic shortfall of achieved market value from best-practice value, and the statistical noise. The difference between the firm's frontier value and the achieved market value is its market-value shortfall, i.e., its lost market value. The ratio of this shortfall to the frontier value is a measure of the bank's market-value inefficiency.

In this chapter, we use the estimates of market-value inefficiency in Hughes, Lang, Mester, Moon, and Pagano (2003) to study the relationship between bank performance and sources of managerial discipline; we report our findings in Tables 2-5. Hughes, Lang, Mester, Moon, and Pagano (2003) discuss the technique for estimating market-value shortfall as follows.

Tobin's $q$ ratio is proxied by the ratio of the market value of the bank's assets to the book value of the bank's assets, where the market value of assets is measured as the sum of the market value of equity and the book value of liabilities and the book value of assets excludes goodwill.

Letting $M V A_{i}$ denote the market value of the $i$ th bank's assets and $B V A_{i}$ their book value of assets less goodwill, the equation of the frontier is given by

$$
M V A_{i}=\alpha+\beta B V A_{i}+\gamma B V A_{i}^{2}+\varepsilon_{i},
$$

where $\varepsilon_{i}=v_{i}-\mu_{i}$ is a composite error term used to distinguish statistical noise, $v_{i} \sim$ iid $\left(0, \sigma_{v}{ }^{2}\right)$, from the systematic shortfall, $\mu_{i}(\geq 0) \sim$ iid $\mathrm{N}\left(0, \sigma_{\mu}{ }^{2}\right)$. The quadratic specification allows the fitted frontier to be nonlinear. This equation is estimated using maximum likelihood. The deterministic kernel defines the best-practice frontier:

$$
F M V A_{i}=\alpha+\beta B V A_{i}+\gamma B V A_{i}^{2} .
$$

The stochastic frontier is composed of the deterministic kernel and the two-sided error term:

$$
\begin{aligned}
S F M V A_{i} & =\alpha+\beta B V A_{i}+\gamma B V A_{i}^{2}+v_{i} \\
& =F M V A_{i}+v_{i} .
\end{aligned}
$$

The difference between the best-practice frontier market value and the achieved value actually observed for the firm defines the bank's market-value shortfall, $\mu_{i}$, and is given by:

$$
\mu_{i}=S F M V A_{i}-M V A_{i}=F M V A_{i}-\left(M V A_{i}-v_{i}\right) .
$$

Note that $\left(M V A_{i}-v_{i}\right)$ gives the noise-adjusted market value of assets.

Since the inefficiency component of the composite error term cannot be directly estimated, it is computed as the expectation of $\mu_{i}$ conditional on $\varepsilon_{i}$ :

$$
E\left(\mu_{i} \mid \varepsilon_{i}\right)=F M V A_{i}-\left(M V A_{i}-E\left(v_{i} \mid \varepsilon_{i}\right)\right)^{7}
$$

\footnotetext{
${ }^{7}$ See Jondrow, Lovell, Materov, and Schmidt (1982), who first proposed computing the firm-specific inefficiency by the conditional expectation; more details of this procedure can also be found in the survey by Bauer (1990).
} 
We measure a bank's market-value inefficiency by normalizing its inefficiency by its frontier value. This shortfall ratio gives lost market value (after correcting for luck) to its bestpractice value and is a gauge of the degree of agency problems in the bank:

$$
\text { market-value inefficiency } y_{i}=E\left(\mu_{i} \mid \varepsilon_{i}\right) / F M V A_{i} .
$$

In this chapter, we present results of regressing market-value inefficiency on various measures of market discipline and governance. 


\section{Table 1. Data definitions and summary statistics}

The data are taken from Hughes, Lang, Mester, Moon, and Pagano (2003) and consist of 169 publicly traded, top-tier bank holding companies (BHCs) in 1993 and 1994.

Market-value inefficiency is derived from a market-value frontier and is the difference between the best-practice potential (frontier) value and the noise-adjusted, observed market value of assets, as a proportion of the potential value. ${ }^{8}$ Market-value inefficiency is measured at the end of 1994. (See the Appendix for further information.)

Insider ownership is the proportion of outstanding shares owned by officers and directors in the year before, i.e., in 1993.

An outside blockholder is defined as a holder of 5 percent or more of outstanding shares based on 13D filings. Blockholder ownership is the percent of outstanding shares held by outsiders in 1993.

The value of a BHC's investment opportunities is measured by fitting a stochastic frontier to the market value of assets as a function of the book value of assets and, in the bank's local markets, the market-weighted, 10-year average macroeconomic growth rate and the BHC's market-weighted Herfindahl index of concentration. A BHC's investment opportunity index is the best-practice market value of the BHC's assets in the local markets in which it operates as a proportion of its book-value investment in assets.

Tobin's $q$ ratio is the market value of assets, net of goodwill, divided by the book value of assets, net of goodwill.

The capital-to-assets ratio is the book value of equity including goodwill divided by the book value of total assets goodwill.

The BHC's Herfindahl index is given by the weighted sum of the BHC's squared share of deposits in each of its local markets where the weights are the proportion of total deposits found in each market.

The average interest rate on loans is total interest earned on loans divided by loans minus nonaccruing loans.

The price of insured deposits is the interest expense of deposits in domestic offices excluding time deposits over $\$ 100,000$ divided by the volume of these deposits.

\footnotetext{
${ }^{8}$ Note that Hughes, Lang, Mester, Moon, and Pagano (2003) misreported the definition of this variable as the shortfall as a proportion of the book value of assets net of goodwill rather than as a proportion of potential value. The values of the variable, however, were correct.
} 
The price of uninsured deposits is the interest expense of domestic time deposits over $\$ 100,000$ divided by the volume of these deposits.

The price of other borrowed money is the expense of foreign deposits, commercial paper, subordinated notes and debentures mandatory convertible securities, securities sold under agreement to repurchase, federal funds purchased, trading account liabilities, other borrowed money, and mortgage indebtedness, divided by the volume of these funds. 


\section{Summary Statistics}

Panel A. Full sample of 169 publicly traded, top-tier bank holding companies

\begin{tabular}{|c|c|c|c|c|c|}
\hline Variable & Mean & Median & Std Dev & Minimum & Maximum| \\
\hline $\begin{array}{l}\text { Book value assets, } \\
\text { net of good will }(\$ 1,000)\end{array}$ & ,796,319 & $1,972,085$ & $27,384,208$ & $159,860.00$ & $211,764,250$ \\
\hline Market-value inefficiency ratio & 0.191 & 0.149 & 0.164 & 0.000961 & 0.697 \\
\hline $\begin{array}{l}\text { Insider ownership }= \\
\% \text { of outstanding shares } \\
\text { held by officers \& managers }\end{array}$ & 12.885 & 7.264 & 13.449 & 0.342 & 66.018 \\
\hline $\begin{array}{l}\text { Outside blockholder ownership = } \\
\% \text { of outstanding shares held } \\
\text { by outside blockholders } \\
\text { (holders of } 5 \% \text { or more of } \\
\text { outstanding shares) }\end{array}$ & 3.307 & 0.000 & 6.555 & 0.000 & 33.051 \\
\hline $\begin{array}{l}\text { Investment opportunity ratio = } \\
\text { size of investment opportunity } \\
\text { set/book value of assets } \\
\text { net of goodwill }\end{array}$ & 1.073 & 1.057 & 0.054 & 1.006 & 1.319 \\
\hline Tobin's $q$ ratio & 1.036 & 1.033 & 0.033 & 0.970 & 1.172 \\
\hline $\begin{array}{l}\text { Capital-to-assets ratio = } \\
\text { book value of equity including } \\
\text { good will/book value of assets } \\
\text { including goodwill }\end{array}$ & 0.085 & 0.082 & 0.016 & 0.044 & 0.135 \\
\hline Herfindahl index & 0.238 & 0.223 & 0.116 & 0.059 & 0.646 \\
\hline $\begin{array}{l}\text { Average interest rate on loans }= \\
\text { interest earned on loans/volume } \\
\text { of loans }\end{array}$ & 0.085 & 0.084 & 0.00777 & 0.0573 & 0.126 \\
\hline $\begin{array}{l}\text { Uninsured deposit interest rate }= \\
\text { interest expense for uninsured } \\
\text { deposits/volume of uninsured deposits }\end{array}$ & $\begin{array}{l}0.0421 \\
\text { its }\end{array}$ & 0.0412 & 0.0102 & 0.00548 & 0.107 \\
\hline $\begin{array}{l}\text { Insured deposit interest rate }= \\
\text { interest expense for insured } \\
\text { deposits/volume of insured deposits }\end{array}$ & 0.0254 & 0.0262 & 0.00564 & 0.00938 & 0.0393 \\
\hline $\begin{array}{l}\text { Other borrowed funds rate }= \\
\text { interest expense for these funds/ } \\
\text { volume of these funds }\end{array}$ & 0.0438 & 0.0413 & 0.0172 & 0.0143 & 0.178 \\
\hline
\end{tabular}


Panel B. More efficient half of the sample (market-value inefficiency ratio < median) 84 publicly traded, top-tier bank holding companies

\begin{tabular}{|c|c|c|c|c|c|}
\hline Variable & Mean & Median & Std Dev & Minimum & Maximum| \\
\hline $\begin{array}{l}\text { Book value assets, } \\
\text { net of good will }(\$ 1,000)\end{array}$ & $22,820,516^{*}$ & $8,763,745$ & $35,679,798$ & $192,094,800$ & $211,764,250$ \\
\hline Market-value inefficiency ratio & $0.0550 *$ & 0.0451 & 0.0409 & 0.000961 & 0.148 \\
\hline Insider ownership & $7.577^{*}$ & 4.869 & 8.632 & 0.342 & 55.11 \\
\hline Outside blockholder ownership & $4.895^{*}$ & 0.0 & 7.900 & 0.0 & 33.051 \\
\hline Investment opportunity ratio & $1.037 *$ & 1.037 & 0.0144 & 1.006 & 1.073 \\
\hline Tobin's q ratio & 1.036 & 1.033 & 0.0269 & 0.983 & 1.129 \\
\hline Capital-to-assets ratio & $0.080^{*}$ & 0.079 & 0.014 & 0.048 & 0.133 \\
\hline Herfindahl index & 0.228 & 0.221 & 0.083 & 0.059 & 0.521 \\
\hline Average interest rate on loans & $0.0823 *$ & 0.0818 & 0.00785 & 0.0573 & 0.115 \\
\hline Uninsured deposit interest rate & 0.0433 & 0.0424 & 0.0123 & 0.00548 & 0.107 \\
\hline Insured deposit interest rate & 0.0249 & 0.0251 & 0.00542 & 0.00938 & 0.0393 \\
\hline Other borrowed funds rate & 0.0430 & 0.0419 & 0.00845 & 0.0291 & 0.0916 \\
\hline
\end{tabular}

Panel C. Less efficient half of the sample (market-value inefficiency ratio $\geq$ median) 85 publicly traded, top-tier bank holding companies

\begin{tabular}{|c|c|c|c|c|c|}
\hline Variable & Mean & Median & Std Dev & Minimum & Maximum| \\
\hline $\begin{array}{l}\text { Book value assets, } \\
\text { net of good will }(\$ 1,000)\end{array}$ & $901,818^{*}$ & 730,513 & 510,839 & 159,860 & $2,378,657$ \\
\hline Market-value inefficiency ratio & $0.324 *$ & 0.317 & 0.125 & 0.149 & 0.697 \\
\hline Insider ownership & $18.131 *$ & 11.985 & 15.235 & 1.931 & 66.018 \\
\hline Outside blockholder ownership & $1.738^{*}$ & 0.0 & 4.390 & 0.0 & 22.994 \\
\hline Investment opportunity ratio & $1.109 *$ & 1.095 & 0.0551 & 1.028 & 1.319 \\
\hline Tobin's q ratio & 1.036 & 1.0321 & 0.0375 & 0.970 & 1.172 \\
\hline Capital-to-assets ratio & $0.0900 *$ & 0.0877 & 0.0169 & 0.0442 & 0.135 \\
\hline Herfindahl index & 0.248 & 0.2310 & 0.141 & 0.0593 & 0.646 \\
\hline Average interest rate on loans & $0.0875^{*}$ & 0.0861 & 0.00681 & 0.0787 & 0.126 \\
\hline Uninsured deposit interest rate & 0.0408 & 0.0408 & 0.00756 & 0.0235 & 0.0780 \\
\hline Insured deposit interest rate & 0.0260 & 0.0269 & 0.00582 & 0.0110 & 0.0387 \\
\hline Other borrowed funds rate & 0.0447 & 0.0408 & 0.0228 & 0.0143 & 0.178 \\
\hline
\end{tabular}

* Significantly different from the mean of the other efficiency subsample at the $10 \%$ or better level. 


\section{Table 2. Regression of market-value inefficiency on insider ownership}

The data are taken from Hughes, Lang, Mester, Moon, and Pagano (2003) and consist of 169 publicly traded, top-tier bank holding companies (BHCs) in 1993 and 1994 and the regressions are used in the course Hughes (2011)

See Table 1 for data definitions.

The dependent variable is market-value inefficiency and the performance equation is estimated by ordinary least squares.

Dependent Variable: Market-Value Inefficiency

\begin{tabular}{|c|c|c|c|c|}
\hline Variable & $\begin{array}{c}\text { Parameter } \\
\text { Estimate }\end{array}$ & $\begin{array}{l}\text { Heteroscedasticity } \\
\text { Consistent } \\
\text { Standard Error }\end{array}$ & t-value & $\operatorname{Pr}>|t|$ \\
\hline Intercept & $-0.85116^{*}$ & 0.22875 & -3.72 & 0.0003 \\
\hline Insider ownership & $-0.00504 * *$ & 0.00217 & -2.32 & 0.0216 \\
\hline$\left(\right.$ Insider ownership) $^{2}$ & $0.00021254 * *$ & 0.00009418 & 2.26 & 0.0254 \\
\hline (Insider ownership) $^{3}$ & $-0.00000217 * *$ & 0.00000105 & -2.06 & 0.0408 \\
\hline Investment opportunity ratio & $1.66887 *$ & 0.14147 & 11.80 & $<0.0001$ \\
\hline $\ln$ (Book value of assets) & $-0.04907^{*}$ & 0.00565 & -8.69 & $<0.0001$ \\
\hline
\end{tabular}

No. of observations $=169$

$\mathrm{R}^{2}=0.9225$

* Significantly different from zero at the $1 \%$ level.

$* *$ Significantly different from zero at the $5 \%$ level. 


\section{Table 3. Regression of market-value inefficiency on outside blockholder ownership}

The data are taken from Hughes, Lang, Mester, Moon, and Pagano (2003) and consist of 169 publicly traded, top-tier bank holding companies (BHCs) in 1993 and 1994 and the regressions are used in the course Hughes (2011).

See Table 1 for data definitions.

The dependent variable is market-value inefficiency and the performance equation is estimated by ordinary least squares.

Dependent Variable: Market-Value Inefficiency

\begin{tabular}{|c|c|c|c|c|}
\hline Variable & $\begin{array}{l}\text { Parameter } \\
\text { Estimate }\end{array}$ & $\begin{array}{l}\text { Heteroscedasticity- } \\
\text { Consistent } \\
\text { Standard Error }\end{array}$ & t-value & $\operatorname{Pr}>|t|$ \\
\hline Intercept & $-0.94457 *$ & 0.21900 & -4.31 & $<0.0001$ \\
\hline Outside blockholder ownership & $0.00256 * * *$ & 0.00137 & 1.87 & 0.0628 \\
\hline (Outside blockholder ownership) $)^{2}$ & -0.00006618 & 0.00005078 & -1.30 & 0.1943 \\
\hline Investment opportunity ratio & $1.71071 *$ & 0.13725 & 12.46 & $<0.0001$ \\
\hline $\ln$ (Book value of assets) & $-0.04750 *$ & 0.00532 & -8.93 & $<0.0001$ \\
\hline
\end{tabular}

No. of observations $=169$

Adjusted $\mathrm{R}^{2}=0.9208$

* Significantly different from zero at the $1 \%$ level.

** Significantly different from zero at the 5\% level.

*** Significantly different from zero at the $10 \%$ level. 


\section{Table 4. Regression of market-value inefficiency on market concentration}

The data are taken from Hughes, Lang, Mester, Moon, and Pagano (2003) and consist of 169 publicly traded, top-tier bank holding companies (BHCs) in 1993 and 1994 and the regressions are used in the course Hughes (2011)

See Table 1 for data definitions.

The dependent variable is market-value inefficiency and the performance equation is estimated by ordinary least squares.

Dependent Variable: Market-Value Inefficiency

\begin{tabular}{|c|c|c|c|c|}
\hline Variable & $\begin{array}{l}\text { Parameter } \\
\text { Estimate }\end{array}$ & $\begin{array}{l}\text { Heteroscedasticity- } \\
\text { Consistent } \\
\text { Standard Error }\end{array}$ & t-value & $\operatorname{Pr}>|t|$ \\
\hline Intercept & $-0.88882 *$ & 0.21458 & -4.14 & $<0.0001$ \\
\hline Herfindahl index & $-0.28964 *$ & 0.09301 & -3.11 & 0.0022 \\
\hline$(\text { Herfindahl index })^{2}$ & $0.37171 * *$ & 0.15097 & 2.46 & 0.0148 \\
\hline Investment opportunity ratio & $1.68158 *$ & 0.13698 & 12.28 & $<0.0001$ \\
\hline $\ln$ (Book value of assets) & $-0.04593 *$ & 0.00526 & -8.73 & $<0.0001$ \\
\hline
\end{tabular}

No. of observations $=169$

Adjusted $\mathrm{R}^{2}=0.9237$

* Significantly different from zero at the $1 \%$ level.

** Significantly different from zero at the 5\% level.

*** Significantly different from zero at the $10 \%$ level. 


\section{Table 5. Regression of market-value inefficiency on market concentration controlling for bank input and output prices}

The data are taken from Hughes, Lang, Mester, Moon, and Pagano (2003) and consist of 169 publicly traded, top-tier bank holding companies (BHCs) in 1993 and 1994 and the regressions are used in the course Hughes (2011).

See Table 1 for data definitions.

The dependent variable is market-value inefficiency and the performance equation is estimated by ordinary least squares.

Dependent Variable: Market-Value Inefficiency

\begin{tabular}{|c|c|c|c|c|}
\hline Variable & $\begin{array}{l}\text { Parameter } \\
\text { Estimate }\end{array}$ & $\begin{array}{c}\text { Heteroscedasticity- } \\
\text { Consistent } \\
\text { Standard Error }\end{array}$ & t-value & $\operatorname{Pr}>|t|$ \\
\hline Intercept & $-0.79832 *$ & 0.20834 & -3.83 & 0.0002 \\
\hline Herfindahl index & $-0.23524 * *$ & 0.10567 & -2.23 & 0.0274 \\
\hline$(\text { Herfindahl index })^{2}$ & $0.30791 * * *$ & 0.16708 & 1.84 & 0.0672 \\
\hline Average interest rate on loans & 0.39197 & 0.48698 & 0.80 & 0.4221 \\
\hline Uninsured deposit interest rate & 0.23088 & 0.35842 & 0.64 & 0.5204 \\
\hline Insured deposit interest rate & $-1.37030 * *$ & 0.59377 & -2.31 & 0.0223 \\
\hline Other borrowed funds rate & 0.02694 & 0.21220 & 0.13 & 0.8992 \\
\hline Investment opportunity ratio & $1.61292 *$ & 0.13022 & 12.39 & $<0.0001$ \\
\hline $\ln$ (Book value of assets) & $-0.04826 *$ & 0.00523 & -9.23 & $<0.0001$ \\
\hline
\end{tabular}

No. of observations $=169$

Adjusted $\mathrm{R}^{2}=0.9238$

* Significantly different from zero at the $1 \%$ level.

$* *$ Significantly different from zero at the 5\% level.

*** Significantly different from zero at the $10 \%$ level. 